\title{
Suur tamm, kuduvad neiud ja punane paat, kadunud harjast rääkimata
}

\section{$\underline{\text { Aado Lintrop }}$}

Selles, et julgesin idapoolsete hõimurahvaste usundite uurimise alalt sooritada nii ulatusliku kõrvalehüppe meie oma regilaulu juurde, on omal kombel süüdi eesti lauluuurijad ise: puuduvad meil ju tänaseni paljude mütoloogilistena tõlgendatavate laulumotiivide arvestatavad käsitlused. Üht või teist regilaulutüüpi või motiivi on vaadeldud küll kursuse-, diplomivõi harukorral isegi magistritöö tasemel, ent ikka on rõhk olnud usundivälistel aspektidel. Ka on kõik need uurimused jäänud laiema levita, raamatuna on ilmunud vaid Tiiu Jaago «Kuldnaine», ent seegi on mõeldud õppematerjaliks regilaulu stilistika alal. Üksikuid regilaulude mütoloogilisi aspekte puudutavaid artikleid on avaldanud Oskar Loorits (Kuldnaise laulust soome keeles), Uku Masing (Ristitud mets), Felix Oinas (suurema osa inglise keeles), Martin Puhvel, Jaan Kaplinski, Tõnn ja Mikk Sarv. Võrreldes regilaulude keele ja poeetika uurimisele pühendatud sadade artiklitega on seda imevähe. Omal kombel julgustasid mind laulude kallale asuma ka mõned Matti Kuusi uurimustes esinevad tõdemused. Näiteks võttis ta lahkumisloengul oma pika ja põhjaliku sampo-uurimise kokku sõnadega: «Mitmeaastasele pingutusele vaatamata ei õnnestunud mul kõigutada Setälä intuitiivset põhioletust $\stackrel{* 1}{1}$, vaid kohati seda täpsustada.» (Kuusi 1985:170). Soome uurimismeetodi mineviku ja tuleviku üle arutledes nentis ta muu seas: "Soome meetodi kriitikud on mõnikord irooniliselt juhtinud tähelepanu sellele, kuidas selle suuna folkloristid ülitäpse detailianalüüsi ja ettevaatliku redaktsioonide võrdlemise järel võivad uurimuse lõpulehekülgedel äkki prohvetlikeks ettenägijateks muutuda ja lõpetada kultuuriajalooliste sünteeside luulendajatena. Asi tundub lootusetuna siis, kui tuleb kokku viia 1800-ndate aastate Ingeris loitsuna või tüdrukute lauluna esinenud värsid ja nende sünniaja vaimne miljöö ühes selle sotsiaalsete suhete ja tähendustega. Mitte ükski teabe käsitlusviis ei vii kaljukindlalt 'õige' tulemuseni; uurijal tuleb rahulduda enam-vähem tõenäoliste hüpoteeside püstitamise ja nende hulgast antud hetkel kõige seletamisvõimelisema valimisega.» (Kuusi 1980: 56.)

Järgnevalt esitatud laulukatkete käsitlus ei põhine tekstikriitilisel meetodil, redaktsioonianalüüsil ega mingil muulgi ainult teksti suhtes rakendataval menetlusel. Olen veendunud, et ei need laulud ega nende ükskõik millised redaktsioonid pole kunagi pärimusena kandnud seda maailmapilti, mille peegeldusi ma leida püüan. Põhjendan oma väidet lühikese arutlusega.

Tekstid, mis peavad põlvest põlve edasi andma mingi grupi religioosseid kujutelmi ning maailmapilti (kusjuures ettekujutused maailmast ei seostu grupisiseselt kunagi usundiga, vaid neid edastatakse tõsiasjadena), peaksid olema vähese sümboliseerituse ja poetiseerituse astmega, muidu ei sisalda nad vajalikku hulka asjakohast informatsiooni. Samas on kõigile usunditele (nagu inimese religioossele kogemusele üldse) omane sõnulseletamatuteks või mõistuseülesteks kuulutatud asjade tõlkimine sõnade keelde, mis tingib sümboolse ja poeetilise väljenduslaadi. Pärimuse kestmiseks on vaja see vastuolu kuidagi ületada. Oletan, et grupi jaoks eriti oluline pärimus edastati (ja edastatakse) kirjakeeleta kultuurides vähemalt kahel tasandil, millest üks on teisest märkimisväärselt rohkem reglementeeritud, sundides pärimust erinevalt sõnastama või isegi ühelt tasandilt teisele tõlkima. Näiteks võib tuua kasvõi handi ja mansi pühad laulud, mida naised-lapsed kuulata ei tohtinud. Ometi teadsid nad nende sisu, ent olid sunnitud seda teisel kujul edasi andma. Nii sai potentsiaalne laulu esitaja lapsepõlvest kaasa ka lauluga seotud ümberjutustatud sisu, mis võis tal 
tulevikus aidata laulu paremini mõista ja "ohjas hoida», et esituslik-poeetiline külg liialt domineerima ei pääseks. Seda, et mütoloogilised laulud olid hantide ja manside jaoks pärimuse edasiandmise seisukohast primaarsed, tunnistab fakt, et jutukangelaste identifitseerimine toimus sageli muistenditesse põimitud lauluvormelite abil (vt. Lintrop 1997: 3435). Uus-Guinea paapuate mütoloogilised laulud aga sisaldavad vaid vihjeid ja märksõnu, mille tähendus õpetatakse väljavalitutele selgeks mitmeastmelise initsiatsiooniprotsessi käigus. Laulud ise on kõigile kuulamiseks (nagu ka meeste majas räägitud jutud - puudusid ju paapua külades vähegi helipidavad seinad), ent müüt salastatud. Antud juhul tuleb asjassepühendatu jaoks esitusel arvesse kolm eri teksti - laul ise, salastatud müüt ja pühendamata inimeste tõlgendus. Võib vast liialdamata öelda, et kirjakeeleta kultuurides on religioossete ja maailmavaateliste asjade edastamisel iga esitus taasloomine, mille käigus kohtuvad vähemalt kaks erilaadi teksti, millest üks on pärimuse edastamise seisukohalt peamine infokandja, teised aga sisaldavad tõlgendusi, kommentaare, suhtumisi, hinnanguid. Selleks aga, et kohustada grupi liikmeid pärimust üha uuesti esitama, luuakse grupisisesed rituaalidel ja (või) riitustel põhinevad institutsioonid, obiugrilastel näiteks karupeied. Tekstide ja rituaali koosmõju võib pärimuse tundjal (kes ei pruugi olla esitaja) mõnel kriitilisel hetkel esile kutsuda üleloomuliku kogemuse, mis traditsioonilisse vormi valatuna omakorda võimendab pärimuse aktuaalsust.

Kui üks ahela lülidest mingil põhjusel kaob, ei püsi muutumatuna ka teised. Kui meie esivanemate mütoloogilised laulud sarnanesid runolauluga, olles üsna suure poetiseerituse astmega, pidid pärimuse edastamise seisukohalt olema peamised muud liiki tekstid. Nende hääbudes või teisenedes kaotasid laulud kokkupuutepunktid aktuaalse usundiga. Kui aga kunagised mütoloogilised laulud olid vähem poetiseeritud (olles seega pärimuse peamiseks kandjaks), võisid muutuse esile kutsuda usundis ja rituaalide tasandil toimuvad nihked. Mõlemal juhul ei tajutud laulu enam kui üht võimalikku grupile olulise informatsiooni edastamise viisi, vaid väärtustati lauliku poeetiline eneseväljendus, mis tõi meie kultuuriruumis kaasa lüüriliste elementide sissetungi, kujundlike (ja seetõttu ka kujunduslike) motiivide suhteliselt suurema iseseisvumise, alliteratsiooni absolutiseerimise ja parallelismi veelgi laiema ulatuse, mille tulemusel moodustusid meile tuntud runo- ja regilaul. Nende side usundiga kujunes hoopis uuelt aluselt, sest neid peeti heal juhul vaid ammumöödunud aegade kaugeks ja uduseks peegelduseks. Sellistena sobisid nad või nende osad küll ajaviiteks või maagiliseks mõjutamiseks (saab ju viimasel eesmärgil kasutada isegi täiesti arusaamatuid tekste), kuid ei väljendanud käibelolevaid uskumusi. Sellepärast ei aitagi lauluvariantide tekstianalüüsist lähtuv võrdlemine meil mõista laulude kunagist mütoloogilist tausta.

Lähtun oletusest, et läänemeresoome laulude suurt tamme pole kasvatanud niivõrd ettekujutused ilmapuust, kuivõrd aastaringiga seotud uskumused ja kombed. Sellepärast võtan vaatluse alla võimalikult paljud suure tamme, nelja neiu ning suvise (ning talvise) pööripäevaga seostuvad laulumotiivid, millele lisan vajalikud kombestikuelemendid.

Paljude runo- ja regilaulude kangelastena esinevad õde ja vend, kusjuures tekst annab mõnikord vaid kaudselt mõista, et tegemist pole tavaliste inimestega. Samamoodi tutvustatakse tegelasi ka obiugri muistendites, mis algavad sageli vormeliga "elasid õde-venda", "elas mos'-naine koos vennaga» või "elas naise poeg koos oma tädi/vanaemaga». Vaid üksikutest vihjetest saab kuulaja aru, et tegemist pole lihtsurelikega. Mõnikord jäävad nad jutu lõpuni identifitseerimata, mõnikord pannakse nad muistendi lõpuosas paika müütilistest lauludest pärinevate vormelitega ${ }_{2}^{*}$, harva öeldakse nende nimed otse välja. Võib üsna kindlalt väita, et mütoloogilise sisuga juttudes tähendab õde või $m o s^{\prime}$-naine kas mõnda jumalust või müütilist esivanemat. Sama kehtib ka venna kohta. Kuna suur osa nendega seotud pärimusest antakse edasi teist liiki tekstina (antud juhul lauludena), on ilma neid tundmata raske mõista lugude 
mütoloogilisi tagamaid. Kui oletame, et meie kultuuriregioonis ei olnud laul pärimuse peamiseks kandjaks, pidid eksisteerima muud laadi tekstid, mis ehk oleksid seletanud, kes on mütoloogiliste laulude õed-vennad. Muutunud kujul meieni jõudnud katkenditest leiame vaid üksikuid vihjeid.

Kõige sagedamini algab suure tamme sünnilugu neiudest, mõnikord on nende arvuks neli (kolm):

Oli ennen nel'l'ä neittü,

koko kolme morshienta,

lähetih hyö

heinän niittoh,

eli korttehen koruh.

Vuokkiniemi (KKR I: 342)

Juba vormel oli ennen, mis paljudes variantides üsna järjekindlalt esineb, viitab sellele, et tegemist pole tavaliste inimestega. Mõnikord öeldakse neide olevat sillatäis või jäetakse arv märkimata nagu Eestis:

Õekesed, hellakesed,

lähme merda pühkimaie,

mereääri äigamaie,

luuad kuldased käessa,

hõbedaised luuaoksad,

vaskised olid luuavarred,

siidised luuasidemed.

Haljala (VK VI:1: 142)

Võib arvata, et kuldse luuaga ei pühi tavaline neiu. Pealegi asetub see ühte mõttelisse ritta laulutüübis 'Hari kadunud' esineva kuldse soaga:

Läksin kulles kuuskejeni, kallis kase latvajeni; sealt suen sulaste päida, kasin karja laste päida, arin peada armutumalt, 
suga kuldane käessa, obedane täie lauda.

Jõhvi (ER I: 302)

Selle laulutüübi mitmetes variantides toimub huvitav metamorfoos - venda kõnetavast õest saab puude ladvust kuldse soaga päid kammiv päike - üleminek, mis on üks eredamaid näiteid lüüriliste motiivide kunagisse mütoloogilisse laulu tungimise tagajärgedest. Matti Kuusi arvab, et neli heina niitvat neidu on tõenäoliselt samalaadsed läänemeresoome ahellaulude nelja kuduva neiuga (Kuusi 1963: 196). Arvan, et nende hulka võib arvata nii merd pühkivad neiud kui ka kuldse soaga kuuske/kaske mineja.

Meie regilauludest esineb nelja kuduva neiu motiiv kõige tähenduslikumalt ahellaulus 'Meri õue all' ('Luust sõrmus'):

Mis seel sormuse
sisessa?
Neli noorta
neitsikesta:
üks seel kuab
kuldavööda,
teine vaalib
vaskivööda,
kolmas poomib
pollesida,
neljas nutab noorta
miesta.
Haljala (VK VI:1:
172)

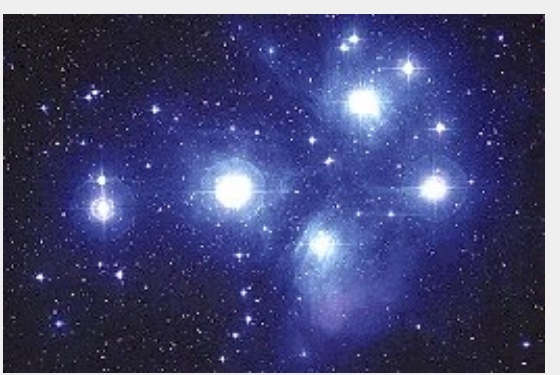

vaskivööda, kolmas poomib pollesida, neljas nutab noorta miesta. 172)

Tähistaevast toetava samba või puu otsas olev Sõel on eesti rahvaastronoomia kõige populaarsem tähtkogu, mille järgi arvati aega ning ennustati ilma, eriti aga seda, millised tulevad kevad ja suvi ning kas tuleb hea või halb viljaaasta. Erinevalt 'Suure tamme' laulu puust on ahellaulu puu või sammas tüüpiline ilmapuu, mille okstel või okste küljes usuti paljude rahvaste usundeis asuvat või puhkavat taevaseid valguseallikaid. Lauluahel viitab selgesti, et kudujate näol on tegemist taevaste neidudega. Muuseas on neid seostatud nii antiikmütoloogia moirade kui muinasskandinaavia nornidega (vt. Sarmela 1995: 212). Et neil võib olla tegemist inimsaatustega, sellele viitab ka Ingerimaa populaarne ahellaul, kus, tõsi küll, esineb vaid üks kuduv neiu: 
Meroi meijen

ikkunalla.

Mikä uipi meroissa?

Sotkoi tuo meroissa

uipi.

Mikä sotkoin siiven

alla?

Kätkyt sotkoin siiven

alla.

Mikä on kätkyen

sisässä?

Poikoi kätkyen sisässä.

Mitä poikoi tekköö:

kirjoikantta kirjuttaa.
Mikä kirjokannen alla?

Neitoi kirjoikannen alla.

Mitä neitoi tekköö?

Kultoikangasta kuttoo,

hopeaista helkyttä̈̈.

Taittui yksi kultoilankoi,

helähtyi hoppealankoi,

neitoi täytyi itkömään.

Hevaa (SKVR IV ${ }_{2}$ : 441)

Järgneb kirjeldus, kuidas pisarad veerevad põskedele, sealt sõlele, sõlelt sukkadele. Varianditi esineb kirjokanne asemel kirjan kansi, mida teadlased peavad hiliseks muutuseks (vt. Setälä 1932: 154). Minu arvates ei või raamatut, õigemini eset, kuhu või millele inimeste elupäevad on kirja pandud, siiski välistada. On ju see üsna laialt levinud kujutelm. Võrdluseks näide handi folkloorist:

$\begin{array}{|ll|}\text { Kuukirja püha maja, } & \text { kevadoravanaha pühasse } \\ \text { päikesekirja püha } & \text { raamatusse, } \\ \text { maja } & \text { sügisoravanaha pühasse } \\ \text { sisemuses, } & \text { raamatusse } \\ \text { kuldsete kapjadega } & \text { seitset kuldset kirja } \\ \text { kabjalise laua } & \text { isand see kirjutab, } \\ \text { juures, } & \text { kuut kuldset kirja } \\ \text { kuldsete kapjadega } & \text { seal ta kirjutab. } \\ \text { kabjalise laua } & \text { (Steinitz 1939: 340-341, } \\ \text { peal } & \text { värsid 25-37.) } \\ & \end{array}$

Tegemist on inimestele kõige lähema jumaluse Maailmavaatava Mehega, kes kannab hoolt inimeste hea käekäigu eest ning on vahemeheks nende ja Kaltash-anki vahel, kes peab inimelude üle arvestust ning määrab nende kestuse. Maailmavaatav Mees tähendab üles inimeste teod (sealhulgas nende poolt toodud ohvrid) ning palub oma emal mitte vähendada inimeste, eriti laste, elupäevi. Muuseas on obiugri keeltes sõnal kiri olnud ligikaudu sama tähendus kui eesti keeles, näiteks tähendab mansi khansungkve nii kirjutamist kui mustriga kirjamist, 
omadussõna khansang aga on nii kirju kui ka kirjatud. Ingeri laulu neiu, kes katkenud lõnga üle nutab, võib sümboliseerida katkenud inimelu pärast kurvastavat jumalust. Muidugi võib kirjokansi tähendada ka taevast. Kuid ka taevas võib olla inimelude ülestähendamise kohaks - väga populaarse uskumuse kohaselt on taevatähti inimeste hingedeks või eludeks peetud:

Tähti arvatakse olevat taevas nii palju kui maapääl inimesi. Kui langevat taevas täht, surra ära üks inimene. Sest ühes inimese surmaga kustuvat ka ära tema inge täht. Suured ja eledad tähed olla rikaste ja väikesed tuhmid vaeste inimeste inged.

ERA II 132, 597/8 (8) Krj

Ingerist on möödunud sajandi 80-ndail üles kirjutatud ka selline laul, kus neiu läheb kodust kõndima, lööb jala ära ning istub nuttes. Teda kutsuvad endaga kuld ja hõbe (ka vask), ent neiu läheb kaasa noorima vennaga

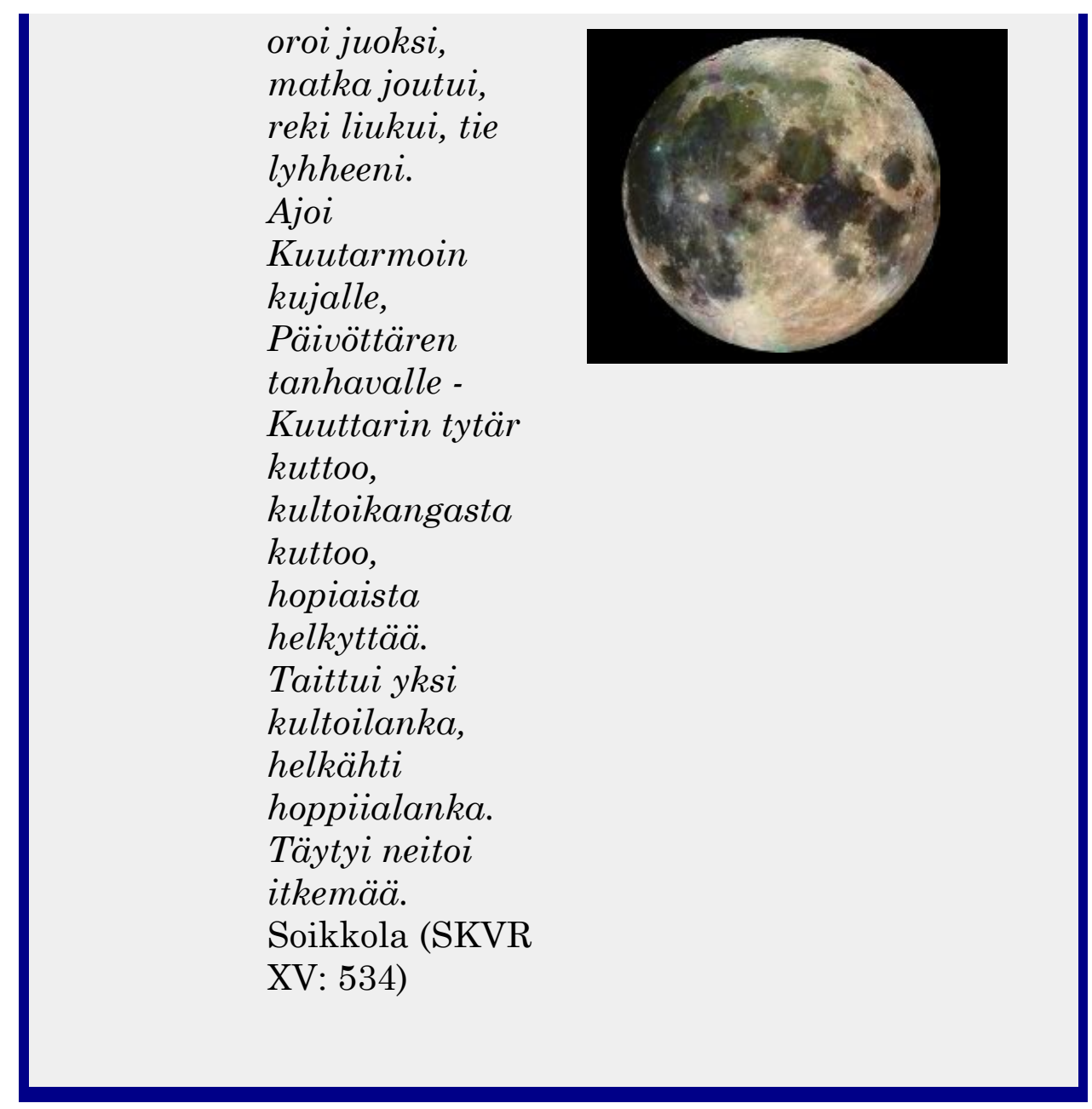


Selles laulus on kuduja selgesti Päikese ja Kuuga seotud. Mõnes variandis sünnib pisaratest kolm jõge, kaks (kolm) mäge, millel kasvab kolm kaske, kaskede otsas kukub kolm kägu:

Yksi käki kullin kukkui,

toine huohteli hoppein,

kolmas käki leinin liekkui.

Soikkola (SKVR XV: 536)

Edasi seostatakse käod isa, ema, vendade ja õdedega ning öeldakse, kellele milline kägu kukub (= keda milline tulevik ootab). Nii on katkenud lõnga kohal nutva neiu seos inimsaatustega veelgi ilmsem.

Karjalas aga liitub Suure tamme motiivile sageli järgmine ahel:

$\begin{array}{|ll|}\text { Pilvesh on } & \\ \text { pisarat shuuret, } & \text { Punotah punaista } \\ \text { pisaresh on } & \text { köyttä, } \\ \text { luojat lammit, } & \text { shituvo meren shivuva, } \\ \text { lammis on veno } & \text { Kannanlahta } \\ \text { punani, } & \text { kuakistuae: } \\ \text { venosessa on } & \text { meri tyynenä pysyise, } \\ \text { nuoret miehet, } & \text { Kannanlakshi } \\ \text { nuoret miehet } & \text { kaunehena. } \\ \text { naimattomat, } & \text { Vuokkiniemi (KKR 1: } \\ \text { viel' on viinan } & 342) \\ \text { juomattomat. } & \\ & \\ \end{array}$

Kahtlemata tähistavad noormehedki mitte inimesi, vaid üleloomulikku sfääri kuuluvaid olendeid, kellest sõltub muu seas ka see, kas meri on sile või tormine. Samas on nad päikesega seotud, sest nii punane paat kui punutav punane köis viitavad loojangu- või koidutaevale. Punetav taevas on ikka endeline olnud, mõnel pool arvatakse praegugi, et kui õhtul on taevas punane, tuleb järgmisel päeval ilus ilm. Eesti laulutüübi 'Kulla põlemine' ahel kinnitab, et tegemist on ilma mõjutavate olenditega - nende võimuses on tuld kustutav vihm: 
Pilves on veepisara, pisaras on puhas purje, purjes on hani madala, hanel on saba sinine, sava pääl on saksa sängi, saksa sängi, kuldamängi, sääl mängib Sulevi puega,

Sulevi, Kalevi puega.

Haljala (VK VI:1: 164)

Muuseas on mõnes variandis sängi lauldud vööd kuduv(ad) neiu(d) (VK III:1, 114 Kuu, VK VI:1, 166 Hlj, ERlA II:1, 234 Äks). Aga tüübis 'Lähme loojale' loole saavad neiud kulla looja loolt/Maarja heinamaalt (ERIA II:1, 231-232). 'Imetegijas' on maad taevaga ühendava köie keerutajaks mõnikord sepp või jumala/Maarja poeg.

Tähenduslik võib olla tõsiasi, et paljudes Karjala lendva sünniloost jutustavates lauludes esineb nii neli (kolm) neidu kui ka kolm noormeest, sageli aga on nende hulk väljendatud kujul

Sisarest on sillan täysi, veikkoja veno punanen.

Suistamo (SKVR VII 4 : 366)

ent võib leida ka sellise variandi

Oisko meitä toine moine, sisareksii sigla täysi, veljeksi veno punane, lähemmä heinoi niitäntäh, korttehien koguontah...

Suojärvi (SKVR VII 4 : 399) 
Kui jääda selle juurde, et heinaniitjad/mere pühkijad pole tavalised inimesed, võime õed seostada taevaste kudujatega, vennad aga pilve punases paadis (loojangu- või koidutaevas) istuvate noormeestega. Niidetud ja kokkukogutud hein põleb ära, tuhast aga kasvab tamm. Olulise detailina lisandub mõnedes Karjala teisendites see, et tuhk jääb kõigepealt päevale või päeva pojale pea pesemiseks:

\begin{tabular}{|c|c|c|}
\hline 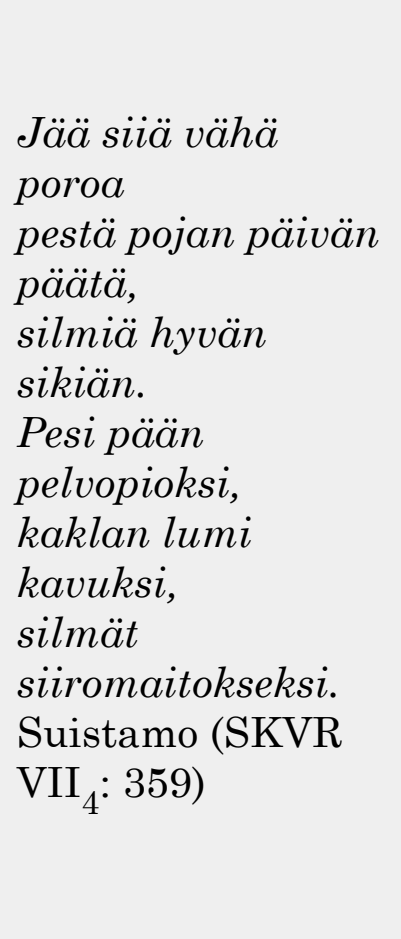 & $\begin{array}{l}\mathrm{V} \\
\tilde{o} \\
\mathrm{i}\end{array}$ & $\begin{array}{l}\text { Minne, kunne tuhkat } \\
\text { pannah? } \\
\text { Loaji pikkune poroja. } \\
\text { Miksi porot pannah? } \\
\text { Päivälle hyvälle peätä } \\
\text { pestä, } \\
\text { sigivölle hyvälle silmii } \\
\text { pestä. } \\
\text { Pesi peän pelvoi } \\
\text { pivoks, } \\
\text { silmät liinan } \\
\text { siemeniksi, } \\
\text { kaglan kanan } \\
\text { muniksi, } \\
\text { muun vartalon muiks } \\
\text { hyviks. } \\
\text { Suojärvi (SKVR VII }: \\
\text { 399-400) }\end{array}$ \\
\hline
\end{tabular}

Paljudes tekstides peseb päev (päeva poeg, paralleelvärssides hea sigija/sigiv/sigitaja) pea linapeoks, kaela kanamunadeks. Arvan, et lina mainimine päeva pea pesemisega seoses pole pelgalt poeetiline kujund. Linakasvu püüti maagiliselt mõjutada just suvise pööripäeva aegu. Vadjas tehti suvistelaupäeval või pühapäeval valvetuld. Tüdrukud lõid vitsaga kolm korda tuld, öeldes «Tudrad tulle ja linad põllule» (Ariste 1969: 75). Eestis visati linatutrad sümboolselt tulle jaanilaupäeva õhtul. Saaremaalt pärinev teade kirjeldab seda nõnda: Jaanitulesse visetakse kolm tokki, esimese juures öoldakse: "Tutrad tulesse," teise juures: "Kasteheinad kargele," kolmanda juures: "Linad minu põllu pääle." (RK IV: 66) Ent Tõstamaal on ka linataimi tulle visatud (samas). Kanamune värviti suviste ajal nii Vadjas kui Eestis (Ariste 1969: 75, RK III: 213). Heina tegemine viitab samuti suvise pööripäeva lähedasele ajale (Jaan tuleb vigatiga, Maarja riihaga järele. Karja. RK IV: 93). Jaanipäeval või enne seda niidetud heinale omistati eriline jõud (RK IV: 28). Oletan, et suvine pööriaeg, nagu talvinegi, ei seostunud vaid konkreetse pööripäevaga, vaid oli ulatuslikum. Udmurtidel näiteks kestis talvine pööriaeg vozho dõr 7. -19. jaanuarini (esimesest jõulupühast Issanda ristimise pühani), suvine pööriaeg invozho aga nelipühast peetripäevani. Võib-olla vihjavad Karjalas levinud värsiread 
Tuliba tuuli Tuulloksesta,

ahava Aunuksen muasta,

tungi heinäset tulehe...

Suistamo (SKVR VII $:$ :362)

pööriaegsetele valvetuledele? Päeva pea pesemine asetub aga ühte poeetilisse ritta pea sugemise ning mere pühkimisega. Kui eesti regilaulu juurde tagasi tulla ja oletada, et mere pühkimine on ühest küljest päikese madalal mere kohal liikumise võrdkuju (vrd. peade sugemine Harja otsimise laulus), teiselt poolt aga konkreetse pööriaegse maagilise tegevuse väljendus, saame skeemi, mille kohaselt suur tamm sünnib suvisel pööriajal. Sellele leiame tuge kombestikust: suviste eel pesti erilise hoolega põrandaid, pühiti puhtaks õu ning jalgrajad (RK III: 213). Ka Vadjas pühiti suviste laupäeval õu puhtaks (Ariste 1969: 76). Jaanipäeval pöörati erilist tähelepanu elamukorrastusele (eriti põrandate küürimisele, RK IV: 28). Pühkmed olid sageli maagilise toimingu objektiks:

$\begin{array}{ll}\text { Külatüdruk } & \text { mere ääri } \\ \text { ud, õeksed, } & \text { äigama! } \\ \text { külanaesed, } & \text { Pühime } \\ \text { naesukesed, } & \text { pühked põlle } \\ \text { võtame } & \text { sisse, } \\ \text { kuldsed } & \text { viime pühked } \\ \text { luuad kätte, } & \text { karjaaida! } \\ \text { hõbedased } & \text { Siin küll } \\ \text { luuavarred, } & \text { tõuseb tõmmu } \\ \text { siidised } & \text { karja, } \\ \text { luuasideme } & \text { sead } \\ \text { d! } & \text { siunakad- } \\ \text { Lähme } & \text { libedad... } \\ \text { merda } & \text { Karuse (ERlA } \\ \text { pühkima, } & \text { II:1: 204) } \\ & \\ & \end{array}$


Ka 'Harja otsimise' laulus puude pühadeks kojutoomise motiivi võib seostada suvistepühadega, mis M. Hiiemäe arvates varem tähistanud suvist pööripäeva (RK IV: 16)

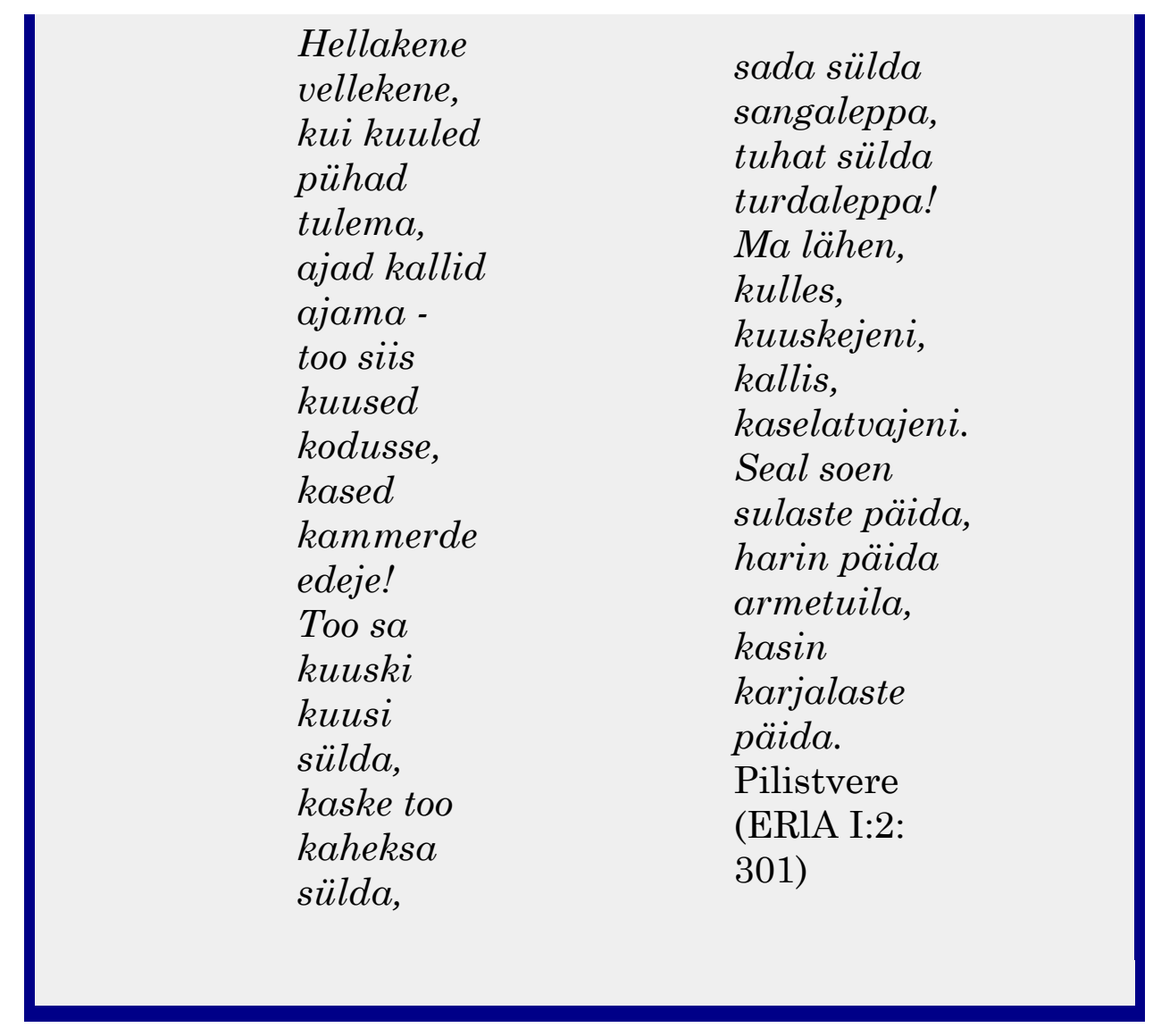

Vormel Jaanikene, kaanikene, tee mul saksa saanikene viitab aga jaanipäevale.

Ingerist möödunud sajandil kogutud laulus aga on peasugemise aeg määratud nii

Mänin rannoille kesoilla, keski kesoilla, heinajalla, paraalla paistehella...

Soikkola (SKVR XV: 393)

Õue ja teeradade pühkimisele inimeste aegruumis vastab mere ja päikese tee (mereäärte) pühkimine jumaluste ilmas. Võimalik, et siin sulgub ring, sest suure tamme raiumisel satuvad laastud sageli merre (Soome ja Karjala teisendites), seega võivad need sattuda ka mere pühkijate luudade ette. Ka heina niitvad neiud leiavad lemmelehe/tammelaastu: 


$\begin{array}{ll}\text { Oli ennen } & \text { arolla } \\ \text { nel'l'ä neittä, } & \text { avaralla. } \\ \text { koko kolme } & \text { Sieltä kashvo } \\ \text { morshienta, } & \text { kaunis } \\ \text { lähetih hyö } & \text { tammi, } \\ \text { heinän } & \text { yleni vihanta } \\ \text { niittoh, } & \text { virpi, } \\ \text { eli korttehen } & \text { pietti pilvet } \\ \text { koruh. } & \text { juokshomash } \\ \text { Löyvettih hyö } & \text { ta, } \\ \text { lemmen lehti, } & \text { hattarat } \\ \text { lemmen lehti, } & \text { hachertamas } \\ \text { tammen } & \text { hta. } \\ \text { lashtu, } & \text { Vuokkiniemi } \\ \text { pantih mualla } & \text { (KKR 1: 342) } \\ \text { kashvavalla, } & \end{array}$

Eelnevat arvesse võttes arvan, et õigus on kõigil neil teadlastel, kes on suure tamme sidunud Linnuteega (esimesena tegi seda U. Harva 1918. aastal). Siiski ei pea ma seda Linnutee sünnilooks sünnilugude tavamõttes, sest rõhk pole niivõrd sellel, kust või kuidas asi alguse sai (vrd. kasvõi raua sünnilooga), kuivõrd suure tamme sünni seostamises igaaastaselt korduva ajavahemikuga. Arvan, et läänemeresoome suur tamm väljendab eelkõige meie boreaalsest asukohast lähtuvat valge ja pimeda aja vaheldumist ehk aastaringi, mida mütoloogilistes lauludes esitati taevase hiigelpuu kasvamise ja raiumisena. Usun, et kujutelma tekkimisel polnud niivõrd oluline see, mis suunda osutas mingil ajal Linnutee haraline ots, kuivõrd tõsiasi, et Linnutee alles ööde pikenedes ja pimenedes nähtavale ilmus, olles talvisel pööriajal selge ilmaga vaadeldav suurema osa ööpäevast ( umbes 17 tundi). Mardilaulude hõbedases örres, kuldses kõrendis võib siis näha eesti paralleeli Viena-karjala lauluridadele
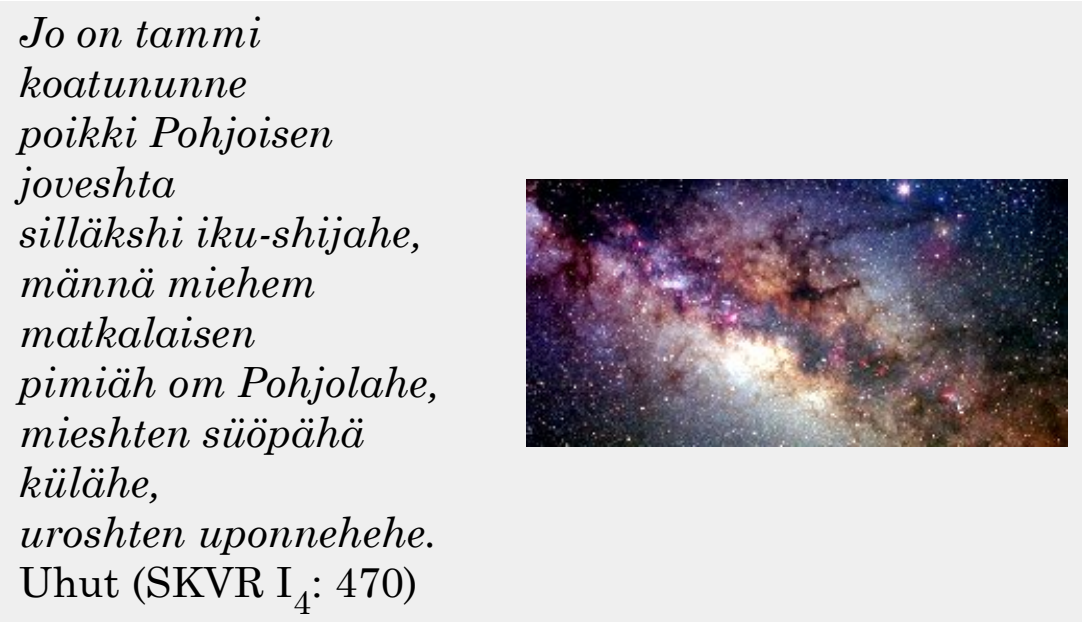
sest kui silda mööda saab minna, saab seda mööda ka tulla. Muuseas sisaldab nimi Linnutee ise viite elavate ja surnute vahelisele ühendusteele. Tuleb arvestada pööriaja erilist tähendust - oli ju nii suvise kui talvise pööripäeva lähedane aeg eriline just selle poolest, et ähmastus muul ajal selge piir inimeste maailma ja üleloomuliku sfääri vahel. Eriti selge väljenduse leidis see meie hingedeajas - aasta kõige pimedamas perioodis, mil Linnutee lumeta öödel kõige paremini paistis. Selles, et läänemeresoome hingedeaeg on talvisest pööriajast varasemaks nihkunud, näengi ühe põhjusena siinset kliimat, mis ei luba novembris püsival lumekattel moodustuda, mistõttu see lume-eelne aeg tundub kõige pimedamana. Kontinentaalses kliimas elavatel udmurtidel oli hingedeaja vasteks jõulujärgne vozhodorr, mil üleloomulikke olendeid usuti küladesse tulevat ja saunades elavat. Sel ajal käisid küla mööda jõulusandid. Tähelepanuväärne on vozho'de seotus veega, neid arvati tulevat ja minevat mööda jõge (mõnel pool peetigi neid pööriaegseteks vetehaldjateks), kogu talvine pööriaeg lõppes pühaga jö võle sulton - jää peal seismine või vozho keljan - vozho ärasaatmine, mille eelõhtul või ööl käidi läbi kõik saunad, öeldes pot tatõs' milemestôles' - minge siit meie juurest välja. Järgmisel hommikul mindi jõejääle, taoti selle vastu kaigastega, karjuti koshki tatõs' - minge siit ära (Pervuhhin 1888: 104-106). Nii peletati pööriaegsed külalised vette ja seejärel allavoolu minema. Udmurdi usundis on jälgi sellest, et ka surnuid on usutud jõge mööda allavoolu lahkuvat. Vesi (jõgi või meri) surnute ilma elavate maast lahutajana või teena surnute maale on laialt levinud kujutelm. Ka kõik eespool vaadeldud laulud seostuvad veega - suga kukub merre, merd pühitakse, sillatäis õdesid/paaditäis vendi, suur tamm kasvab suure haugi seljas, suur tamm saarel, suur tamm kukub sillaks jne.

Kuigi sõtta läinud noormehe või katkenud lõnga pärast nutvas neius võib näha inimestele kaasa tundva jumaluse jooni, ühendab neidusid see, et nende tegevus kutsub esile surma. Merest suga otsiv päev/neiu leiab sageli mõõga *3ㅜㄴ lõng katkeb kuduja käes - kägu kukub leina, maharaiutud suur tamm saab manalateeks, tamme laastudest (sageli esimestest puu raiumisel löödud laastudest) aga tehakse lendvanooled, mis pimeda laskja käe läbi tabavad inimest:

$\begin{array}{|ll|}\text { Kolm'om } & \text { Ampu toisen } \\ \text { poikoa } & \text { nuoliasa } \\ \text { pahalla: } & \text { moa-emähä } \\ \text { üks'on rujo, } & \text { jalkohoinsa; } \\ \text { toin' on } & \text { moa oli } \\ \text { rampa, } & \text { Manalla } \\ \text { kolmasi peri- } & \text { männä, } \\ \text { sokie; } & \text { kankas } \\ \text { rujo jousta } & \text { kahtia } \\ \text { jännittüvi, } & \text { hajota; } \\ \text { rampa nuolie } & \text { ei sitä sieltä } \\ \text { vanuvi, } & \text { peritä! } \\ \text { ampuja peri- } & \text { Ampu } \\ \text { sokie. } & \text { kolmannen } \\ \text { Saipa nuolet } & \text { nuoliansa } \\ \text { valmeheksi. } & \text { kohti vuorta } \\ \text { Ampu kerran } & \text { korkieta, } \\ \text { nuoliansa } & \text { vasten } \\ \text { taivosehe } & \text { varvikko- } \\ & \end{array}$




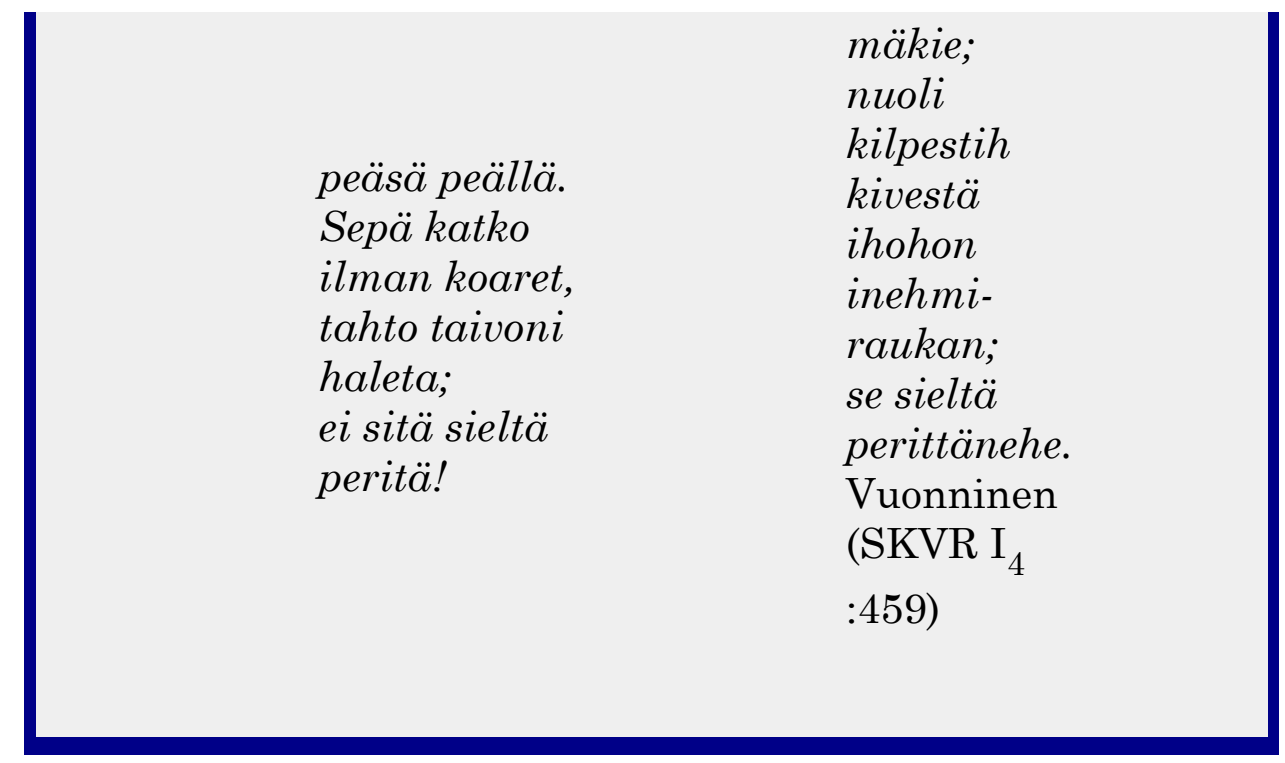

Mõnedes idapoolsetes lauluvariantides sünnib suur tamm otseselt Põhjala/Toonela/Manala neiu juuksekarvast ja (või) kammipiist (jälle pea sugemise motiiv). Ka on tamme kasvukohaks mõnes laulus Põhjala või Toonela. Mõnes põhjapoolses lauluvariandis pistab heina põlema põhjakaarest (Lapist, Turjast) tulnud röövlind või laplane. Pimedus on surnuteilma iseloomulik tunnus vist kõigis usundites, puu ja surma vahelise seose leiame aga laialt levinud ja sageli ilmapuuga segunevast elupuu-kujutelmast.

Laulude neli (kolm) kuduvat/merd pühkivat/heina niitvat neidu sümboliseerivad üleloomulikke olendeid, kellest sõltub aastaaegade vaheldumine, aja kulg ning inimeste saatus. Nende konkreetseid vasteid mütoloogias pole võimalik välja selgitada, tõenäoliselt pole neid sellistena olnudki. 'Harja otsimise' laulu päikese ja neiu vaheldumist ning 'Meri õue all' ahela taevasi kudujaid arvestades võivad nad mõnikord olla taevakehade poeetilisteks vasteteks (näiteks Päike, Kuu, Koidu- ja Ehatäht). Paljudes laulutüüpides esinev vöö kudumine on parim võrdkuju aja kulgemise (elu) märkimiseks. See võimaldab ka mõttelise paralleeli pea kammimise soa, vöösoa ning mõlema tegevuse vahel.

Arvan, et ahellaulude taevast toetava tamme/samba ja 'Suure tamme' laulu hiigelpuu näol on meil tegemist kolme erineva arhetüüpse kujutelma segunemisega, mis on väljenduse leidnud üle maailma levinud ilma- ja elupuuga seotud uskumustes. Neid on kujundanud a) ettekujutused taevast üleval hoidvast ja (või) taevakehasid toetavast puust, sambast või mäest (maailma teljest), mis korruselise maailmapildi puhul on ühtlasi ühendusteeks eri ilmade vahel, b) uskumused puust, mis ühel või teisel viisil põhjustab surematust või surma ja c) last but not least müüdid jumalustest, kes oma olemuse või tegevusega (sealhulgas nende surm ja taassünd) kutsuvad esile öö ja päeva ning aastaaegade vaheldumise.

Viimasele arhetüübile viitab kaudselt ka see suure tamme sündimise motiiv, mille kohaselt puu hakkab kasvama isa akna alla/venna väravasse/kandja kaevuteele kallatud õllevahust. Rahvalauludes üldiselt kehtiva malli kohaselt võib väita: sellega antakse mõista, et kallaja on naissoost. Seda kinnitavad ka lauluvariandid, kus õlut tuuakse pisikese peekriga: 
Olin joutossa Jumalan, piossa pyhä Kalervo, tuotii tuopilla olutta, pikarilla pienimmällä.

Narvusi (SKVR III 1 : 329)

Ka see, et abi saamiseks (puu raiumiseks) pöördutakse venna poole, mõnikord otse välja öeldes oli miulla aino vello, aino vello pikkaraine niiku muilla tyttölöillä (samas), ei jäta kahtlust, et jumalate peole sattunu oli neiu. Ent milline naissoost olevus võib viibida sellisel joomaajal? Eks ikka seesama taevaste kudujate või mere pühkijate laadi olevus. Kui oletame, et soa merre pillamine (resp. harja otsimine), mere pühkimine ja suure tamme kasvamine väljendavad üht ja sama protsessi või selle eri etappe, võime mõtteliselt siduda ka värsid:

$\begin{array}{ll}\text { Oli mul üksi } & \\ \text { ainus venda. } & \\ \text { Kuulis ta } & \text { Jouduin juottoon } \\ \text { pühad tulevad, } & \text { jumalan, } \\ \text { kalli aegu } & \text { käräjään } \\ \text { arvatavad: } & \text { Väinämöisen, } \\ \text { ta tõi kuused ju } & \text { piiruun Pyhän } \\ \text { koeasse, } & \text { Kalervon. } \\ \text { kased kamre } & \text { Tuotiin tuopilla } \\ \text { lä̈̈ve alla. } & \text { oloja, } \\ \text { Võtsi ma arja } & \text { pikarilla } \\ \text { ju piosse, } & \text { pienimmällä. } \\ \text { vaske raua } & \text { Hiiv oli alla, vaahto } \\ \text { kaindelusse, } & \text { päällä... } \\ \text { läksi kuldse } & \text { Soikkola (SKVR } \\ \text { kuuse otsa... } & \left.\text { III }_{1}: 166\right) \\ \text { Hanila (ER I: } & \\ 325) & \\ & \end{array}$

M. Kuusi seostab Päivälä peo motiivi balti-laenulise Päikese ja Kuu pulmapeoga (Kuusi 1963: 142-146). Läti ja leedu folkloori mõju vaidlustamata tahaksin vaid märkida, et Päike esineb naissoost olendina ka idapoolsete soome-ugri rahvaste mütoloogias. Pulm aga ei pruukinud vanasti omada seda tähendust, mis praegu või saja aasta eest. Võimalik, et sõna pulm või pulmad kasutati kunagi mitmesuguste eri riituste tähistamiseks. Näiteks leidub sõna sjuan (pulm) udmurdi keeles nii uude majja kolimise (korka sjuan), uue palvekoja kasutuselevõtu (mudor sjuan), kevadiste põllutööde lõpu (busõ sjuan) kui ka surnutele ohverdamisega (val sjuan) seotud riituste nimetustes. Pulmarongiga ja pulmaviise lauldes toimetati nii ohvrihiie (lud, keremet) kolimist kui ka surnud vanematele ohvri viimist (jõrpõd sjoton). Lisaks uskusid udmurdid, et vetehaldjad ja metshaldjad peavad kaks korda aastas pulmi. Kui sõna pulm on 
meilgi laiemalt kasutusel olnud (võib-olla vihjab sellele sõna verepulm), on mõeldav selle algupärane kasutamine ka teatud pööriaegsete riitustega seoses. Kui aga pulmal meie kultuuriregioonis nii ulatuslikku tähendust polnud, võis ta usundiliselt suhteliselt neutraalse riitusena omandada kristluse tulekuga varasemast hoopis olulisema kaalu, jäädes üheks vähestest kiriku ja ilmaliku võimu poolt aktsepteeritavatest ristiusueelsest ajast lähtuvatest kombetäitmistest meie esivanemate elus. Sel juhul võis ta liita elemente mitmetest eri riitustest.

Rituaalne õllejoomine (kahi) ja või õlle ohverdamine oli tõenäoliselt omal kohal nii pulmas kui oluliste kalendripühade ajal. Ses suhtes on kõnekad mitmed udmurdi pühade nimetused: tolsur (talveõlu, praegu langeb kokku esimese jõulupühaga), gerõ sektan (adra kostitamine, kevadkünni püha), kuarsur (leheõlu, Alnashi rajooni ristimata udmurdid tähistavad seda 12. juulil), guzhem juon (suvine joomaaeg, peetripäev, 12. juuli), sizjõl juon (sügisene joomaaeg, sügispüha novembri lõpus-detsembri algul).

Kui mööname, et laulutüüpide 'Hari kadunud' ja 'Suur tamm' puhul võib olla tegemist suvise pööripäeva ajal peetud peoga, siis võib õllevahu mahakallaja olla seesama puulatva minev kuldsoaga neiu/päike. Toiming ise võib viidata pööriaegsele maagiale (nagu mere pühkiminegi). Oluline on see, et inimeste aegruumis üsna mõõdukat viljakust taotlev toiming põhjustab jumaluste ilmas suuri nihkeid. Võib öelda, et printsiip quod licet Jovi non licet bovi kehtib antud juhul vastupidi. Väga paljude rahvaste mütoloogias levinud põhimõtte kohaselt panevad jumalused kehtivale maailmakorrale aluse just reegleid rikkudes või pahaaimamatult (oma võimeid arvestamata) tegutsedes. Loomiseaegadel kehtivaid seadusi eirates sünnitab valgus või seda valdav jumalus ise pimeduse või laskub surnuteriiki, et astuks tegevusse kangelane (päästja), kes pimeduse ära võidab või jumaluse elule tagasi annab. Et kõik korduks üha uuesti.

\section{Viidatud allikad:}

\section{Käsikirjalised:}

ERA $=$ Eesti Rahvaluule Arhiivi kogu

\section{Trükitud:}

Ariste, P. 1969. Vadja rahvakalender. ENSV Teaduste Akadeemia Emakeele Seltsi Toimetised nr. 8. Tallinn.

ER I = Eesti rahvalaulud Dr. Jakob Hurda ja teiste kogudest. Esimene köide. Eesti

Kirjanduse Seltsi Toimetused nr 21. Tartu 1926.

ERlA I:2 = Eesti rahvalaulud. Antoloogia. Toimetanud Ü. Tedre. I köide, 2. vihik. Tallinn 1969.

ERIA II:1 = Eesti rahvalaulud. Antoloogia. Toimetanud Ü. Tedre. II köide, 1. vihik. Tallinn 1970.

KKR I = Karjalan kansan runot I. Kalevalanaiheiset kertovaiset runot. Kokoonpannut V. Jevsejev. Tallinn 1976. 
Kuusi, M. 1963 = Suomen kirjallisuus I. Kirjoittamaton kirjallisuus. Keuruu.

Kuusi 1980 = Kuusi, M., Honko, L., Virtanen, L., Pentikäinen, J. Perinteentutkimuksen perusteita. Porvoo.

Kuusi, M.1985. Perisuomalaista ja kansainvälistä. Suomalaisen Kirjallisuuden Seura.

Tietolipas 99. Helsinki.

Lintrop, A.1997. Väike mos'-naine. Ühe (muinas)jutu lugu. Mäetagused nr. 3 Tartu.

Pervuhhin N. G. 1888 = Eskizõ predanii i bõta inorodtsev Glazovskogo ujezda. Eskiz 2. Vjatka.

RK III = Eesti rahvakalender III. Koostanud M. Hiiemäe. Tallinn 1984.

RK IV = Eesti rahvakalender IV. Koostanud M. Hiiemäe. Tallinn 1985.

Sarmela, M. 1995. Suomen perinneatlas. Suomen kansankulttuurin kartasto 2. Folklore.

Suomalaisen Kirjallisuuden Seuran Toimituksia 587. Helsinki.

Setälä, E. N. 1932. Sammon arvoitus. Isien runous ja usko I. Helsinki.

$\mathrm{SKVR} \mathrm{I}_{4}=$ Suomen Kansan Vanhat Runot I. Vienan läänin runot 4. Julkaissut A. R. Niemi.

Suomalaisen Kirjallisuuden Seuran Toimituksia 121. Helsinki 1921.

SKVR III 1 = Suomen Kansan Vanhat Runot III. Länsi-Inkerin runot 1. Julkaissut V.

Salminen. Suomalaisen Kirjallisuuden Seuran Toimituksia 139. Helsinki 1915.

SKVR $\mathrm{IV}_{2}=$ Suomen Kansan Vanhat Runot IV. Keski-Inkerin runot 2. Julkaissut V. Salminen.

Suomalaisen Kirjallisuuden Seuran Toimituksia 140. Helsinki 1926.

SKVR VII 4 = Suomen Kansan Vanhat Runot VII. Raja- ja Pohjois-Karjalan runot 4.

Julkaisseet K. Krohn ja V. Alava. Suomalaisen Kirjallisuuden Seuran Toimituksia 143.

Helsinki 1933.

SKVR XV = Suomen Kansan Vanhat Runot XV. Runoja Henrik Florinuksen, Kristfrid

Gananderin, Elias Lönnrotin ja Volmari Porkan kokoelmista. Toimittaneet M. Kuusi ja S.

Timonen. Suomalaisen Kirjallisuuden Seuran Toimituksia 685. Helsinki 1997.

Steinitz, W. 1939. Ostjakische Volksdichtung und Erzählungen aus Zwei Dialekten. 1. Teil.

Õpetatud Eesti Seltsi Toimetused XXXI. Tartu.

VK III:1 = Vana Kannel III. Kuusalu vanad rahvalaulud I. Toimetanud H. Tampere. Tallinn 1938.

VK VI:1 = Vana Kannel VI:1. Haljala regilaulud. Laugaste, E. Tallinn 1989.

\section{Kommentaarid}

1. E. Setälä oletas, et eksisteerib kaks eri sampo-laulude tsüklit, millest üks esitab maailmaloomise jätkuna sampo tagumise ja selle röövimise, teine aga keskendub Põhjala neiu kosimisele, esitades sampo tegemist ühena mitmest neiu saamiseks vajalikust tööst.

2. Näiteks lõik «Ise lähen oma jooksva hobuse kujulisse linna, oma sammuva hobuse kujulisse linna. Väikeste tüdrukute hingi hoides olen seal, väikeste poiste hingi hoides elan seal» (Steinitz 1939: 263) ütleb kuulajale, et tegemist on Püha Linna Taadiga.

3. Mõõk või rist taevas kui sõja märk:

Kui päikese ümber on mõni kuju, näit. rist, siis arvatakse tulevat sõda. Nii näinud 1914. a. Valgjärve valla Künnapistu talu peremees taevas päikese kõrval olevat risti. ERA II 203, 275 (4) Ote.

Sõjamärgid on teised: kui siin ilmasõda oli, siis meil oli siin Siimu kohal elepunane rist ja Tallinna kohas oli valge mõek. ERA II 77, 283 (77) Hag. 